\title{
Cultured Fibroblast Monolayers Secrete a Protein That Alters the Cellular Binding of Somatomedin-C/Insulinlike Growth Factor I
}

\author{
D. R. Clemmons, R. G. Elgin, V. K. M. Han, S. J. Casella, A. J. D'Ercole, and J. J. Van Wyk \\ Departments of Medicine and Pediatrics, University of North Carolina School of Medicine, Chapel Hill, North Carolina 27514
}

\begin{abstract}
We studied somatomedin-C/insulinlike growth factor (Sm-C/ IGF-I) binding to human fibroblasts in both adherent monolayers and in suspension cultures. The addition of Sm-C/IGF-I in concentrations between 0.5 and $10 \mathrm{ng} / \mathrm{ml}$ to monolayers cultures resulted in a paradoxical increase in ${ }^{125} \mathrm{I}-\mathrm{Sm}$-C/IGF-I binding and concentrations between 25 and $300 \mathrm{ng} / \mathrm{ml}$ were required to displace the labeled peptide. The addition of unlabeled insulin resulted in no displacement of labeled Sm-C/IGF-I from the adherent cells. When fibroblast suspensions were used $\mathrm{Sm}-\mathrm{C} /$ IGF-I concentrations between 1 and $10 \mathrm{ng} / \mathrm{ml}$ caused displacement, the paradoxical increase in ${ }^{125} \mathrm{I}-\mathrm{Sm}$-C/IGF-I binding was not detected, and insulin displaced $60 \%$ of the labeled peptide. Affinity cross-linking to fibroblast monolayers revealed a 43,000mol wt ${ }^{125} \mathrm{I}-\mathrm{Sm}$-C-binding-protein complex that was not detected after cross-linking to suspended cells.

The 43,000-mol wt complex was not detected after crosslinking to smooth muscle cell monolayers, and binding studies showed that ${ }^{125} \mathrm{I}-\mathrm{Sm}-\mathrm{C} / \mathrm{IGF}-\mathrm{I}$ was displaced $>90 \%$ by $\mathrm{Sm}-\mathrm{C} /$ IGF-I using concentrations between 0.5 and $10 \mathrm{ng} / \mathrm{ml}$. Because fibroblast-conditioned medium contains the 43,000-mol wt complex, smooth muscle cells were incubated with conditioned medium for $24 \mathrm{~h}$ prior to initiation of the binding studies. ${ }^{125} \mathrm{I}-\mathrm{Sm}$ C/IGF-I-binding increased 1.6-fold compared to control cultures and after cross-linking the $43,000-m o l$ wt complex could be detected on the smooth muscle cell surface. Human fibroblast monolayers secrete a protein that binds ${ }^{125}$ I-Sm-C/IGF-I which can be transferred to the smooth muscle cell surface and alters ${ }^{125}$ I-Sm-C/IGF-I binding.
\end{abstract}

\section{Introduction}

Cultured human skin fibroblasts have been studied extensively as a model to determine the effects of somatomedins on cell growth and DNA synthesis $(1,2)$. Several investigators have analyzed the characteristics of binding of ${ }^{125} \mathrm{I}$-somatomedin-C/insulinlike growth factor I (Sm-C/IGF-I) ${ }^{1}$ to cultured fibroblasts and compared its binding properties with its cell growth-stimDr. Clemmons is on leave to the National Institutes of Health.
Received for publication 3 July 1985 and in revised form 21 January
1986.

1. Abbreviations used in this paper: DME, Dulbecco's modified Eagle's medium; DSS, disuccinimidyl suberate; DTT, dithiothreitol; EGF, epidermal growth factor; FCS, fetal calf serum; MEM, Eagle's minimum essential medium; PAGE, polyacrylamide gel electrophoresis; Sm-C/IGFI, somatomedin-C/insulinlike growth factor-I.

J. Clin. Invest.

(C) The American Society for Clinical Investigation, Inc.

0021-9738/86/05/1548/09 \$1.00

Volume 77, May 1986, 1548-1556 ulating properties $(3,4)$. To perform binding studies, suspended cell systems have been commonly used (3-5). Suspended fibroblasts have been shown to possess two types of somatomedin receptors $(6,7)$. The type $I$ receptor has two subunits, $M_{\mathrm{r}}$ $=135,000$ (alpha) and 95,000 (beta), and binds Sm-C/IGF-I with a higher affinity than IGF-II and both with a greater affinity than for insulin; whereas the type II receptor has an $M_{\mathrm{r}}$ $=260,000$, binds IGF-II preferentially, and does not bind insulin. In order to determine the effects of somatomedins on DNA synthesis, however, adherent monolayer cultures must be used because fibroblasts in suspension do not undergo DNA synthesis and division. Exposure to trypsinization and removal of the cells to create suspended cell preparations have been shown to alter the binding of peptide growth factors to cell surface receptors (8) and various conditions such as treatment at $4^{\circ} \mathrm{C}$ and the use of chelating agents have been adopted in order to minimize these alterations. It has been reported that human fibroblast monolayers possess specific $\mathrm{Sm}-\mathrm{C} / \mathrm{IGF}-\mathrm{I}$ receptors, that bound $\mathrm{Sm}-\mathrm{C} /$ IGF-I is fully dissociable, that displacement of bound ${ }^{125} \mathrm{I}-\mathrm{Sm}$ C/IGF-I occurs at concentrations of unlabeled Sm-C/IGF-I between 1 and $100 \mathrm{ng} / \mathrm{ml}(9,10)$, and that insulin when added at a concentration of $10 \mu \mathrm{g} / \mathrm{ml}$ displaces $>60 \%$ of ${ }^{125} \mathrm{I}-\mathrm{Sm}-\mathrm{C} / \mathrm{IGF}$ I from the monolayers. In contrast other investigators have reported that although there are type I receptors present in fibroblast monolayers, binding to the type I receptor may represent only a small portion of the total ${ }^{125} \mathrm{I}-\mathrm{Sm}$-C/IGF-I that is bound (11).

In attempting to perform similar binding studies we were not able to effectively displace labeled Sm-C/IGF-I from fibroblast monolayers using concentrations in the range of 1.0-10 $\mathrm{ng} / \mathrm{ml}$, and the addition of insulin resulted in no displacement. Because monolayer cultures are required to demonstrate SmC/IGF-I stimulation of replication, we undertook studies using monolayer cultures to define the factors responsible for our inability to displace the labeled peptide effectively and to test the hypothesis that an additional cell surface protein was present that could bind Sm-C/IGF-I but not insulin.

\section{Methods}

Cell culture techniques. Human fibroblasts were purchased from the Human Mutant Genetic Cell Repository (Camden, NJ) or obtained from foreskins of newborn donors. Fibroblasts that were purchased were dermal in origin and were obtained from donors of varying ages. These include GM-10, 12 wk fetal; GM-4392, 16 wk fetal; GM-4525, 17 wk fetal; GM1437, newborn; GM-498, 3 yr; GM-1362, 14 yr; GM-6291, 90 yr, GM731, 96 yr. All cultures were plated in plastic petri dishes (Falcon Labware, Oxnard, CA) using Eagle's minimum essential medium (MEM) supplemented with penicillin $100 \mathrm{U} / \mathrm{ml}$, streptomycin $100 \mu \mathrm{g} / \mathrm{ml}$, purchased from Grand Island Biological Company (Gibco, Grand Island, NY) and $10 \%$ bovine serum (Colorado Serum Co., Denver, $\mathrm{CO}$ ). Fetal calf serum (FCS), used in some experiments, was purchased from two sources; HyClone Laboratories (Denver, CO; lot 1 10454) and Gibco (lot 36K824). Cells were routinely cultured in 10-cm dishes (Falcon 3001) in MEM 
containing $10 \%$ calf serum and were incubated at $37^{\circ} \mathrm{C}$ in a humidified atmosphere containing $5 \% \mathrm{CO}_{2}$ and $95 \%$ air. The medium was changed every third day and the cells were harvested by trypsinization (trypsin $0.1 \%$, EDTA $0.03 \%$, Gibco) and replated approximately once every 10 d using the split ratio of 1:4. Both stock and test cultures were examined at monthly intervals for Mycoplasma pneumoniae and were found to be uncontaminated. For studies of ${ }^{125} \mathrm{I}-\mathrm{Sm}-\mathrm{C} / \mathrm{IGF}-\mathrm{I}$ binding stock cultures were subcultured into 24-well plates (Falcon 3004, 16-mm diam) using a plating density of 10,000 cells/ $\mathrm{cm}^{2}$ except where variations in plating density were required to achieve differences in final cell density. Cells were cultured for $3 \mathrm{~d}$ in MEM supplemented with 10\% FCS then the medium was changed and the incubation continued for an additional 3 d. Cell number was determined in triplicate wells using a Coulter Counter (Coulter Electronics, Inc., Hialeah, FL) on the day that the binding experiment was performed.

Determination of ${ }^{125} I-S m-C / I G F-I$ binding to monolayer fibroblast cultures. Quiescent monolayers were washed three times with phosphatebuffered saline (PBS) and then the cultures were exposed to binding medium containing MEM plus Hepes $20 \mathrm{mM}$ and $0.1 \%$ bovine serum albumin (BSA) (pH 7.4). ${ }^{125} \mathrm{I}-\mathrm{Sm}-\mathrm{C} / \mathrm{IGF}-\mathrm{I}$ (prepared as described below) was added at a concentration of $80,000 \mathrm{cpm} /$ well in a final incubation volume of $0.25 \mathrm{ml}$. After a 2-h incubation at $8^{\circ} \mathrm{C}$ (there was no further increase in binding during a 3- or 4- $\mathrm{h}$ incubation) the medium was aspirated, the cells were washed three times with cold PBS, and then solubilized using $0.3 \mathrm{~N} \mathrm{NaOH}$ for $1 \mathrm{~h}$ at $22^{\circ} \mathrm{C}$. Cell lysates were transferred to plastic tubes and ${ }^{125} \mathrm{I}-\mathrm{Sm}$-C/IGF-I that was cell associated was determined in a Beckman gamma spectrometer (Beckman Instruments, Inc., Palo Alto, CA). Nonspecific binding was determined by subtracting the radioactivity bound in the presence of an excess $(1.0 \mu \mathrm{g} / \mathrm{ml})$ of unlabeled $\mathrm{Sm}-\mathrm{C} / \mathrm{IGF}-\mathrm{I}$ that had been partially purified by a previously described method (12). Total radioactivity bound was consistently in the range of $5-9 \%$ and nonspecific binding was consistently $<15 \%$ of the total bound or the experiment was discarded. In all experiments in which competition curves were generated, unlabeled Sm-C/IGF-I or insulin was added at increasing concentrations varying between Sm-C/IGF-I 0.1 and $300 \mathrm{ng} /$ $\mathrm{ml}$ or insulin between 1.0 and $10.0 \mu \mathrm{g} / \mathrm{ml}$.

Suspended fibroblast cultures. Fibroblast cell suspensions to be used for binding studies were prepared as follows: confluent monolayers were treated with $0.1 \%$ trypsin in $0.03 \%$ EDTA for $1 \mathrm{~min}$ at $24^{\circ} \mathrm{C}$ and the reaction was stopped by addition of MEM plus $10 \%$ FCS. The cells were pelleted then resuspended in $0.25 \mathrm{ml}$ of binding buffer and added to 12 $\times 75$-mm polystyrene tubes $\left(1-1.5 \times 10^{6}\right.$ cells/tube). ${ }^{125} \mathrm{I}-\mathrm{Sm}-\mathrm{C} / \mathrm{IGF}-\mathrm{I}$ $(120,000 \mathrm{cpm})$ was added to each tube. Tubes were incubated for $2 \mathrm{~h}$ at $8^{\circ} \mathrm{C}$ with agitation every $15 \mathrm{~min}$ then washed once with $0.5 \mathrm{ml}$ of PBS and once with $1.0 \mathrm{ml}$ of PBS. After centrifugation the cell pellet was counted.

Preparation of growth factors. Pure preparations of Sm-C/IGF-I were used in all experiments except to determine nonspecific binding. The purification procedure and criteria for purity have been previously published (13). Purified Sm-C/IGF-I was iodinated by a modified chloramine$T$ method (14) to a specific activity of $300 \mu \mathrm{Ci} / \mu \mathrm{g}$. After iodination the peptide was further purified by affinity chromatography using a Sepharose-linked IgG Sm-C/IGF-I antibody. Impure Sm-C/IGF-I that was used to determined nonspecific binding was purified by acid extraction of acromegalic plasma followed by SP-Sephadex and G-50 Sephadex gel filtration chromatography as previously published (12). Porcine (PJ-5682) and human insulin were a gift from the Eli Lilly Co. (Indianapolis, IN). IGF-II was purified by a previously described method and purity was confirmed by amino acid sequencing (15).

Preparation of conditioned medium. Quiescent fibroblast or smooth muscle cell monolayers that had been grown to confluency on $10-\mathrm{cm}$ plates were washed three times with PBS and exposed to serum-free MEM for $72 \mathrm{~h}$ at $37^{\circ} \mathrm{C}$. The conditioned medium was removed, centrifuged at $2,000 \mathrm{~g}$ for $15 \mathrm{~min}$ to remove cellular debris, and stored at $-20^{\circ} \mathrm{C}$ until use (usually within $2 \mathrm{wk}$ ).

Determination of Sm-C/IGF-I binding to smooth muscle cultures. Smooth muscle cells were isolated from the aortas of 3-wk-old piglets by a previously published method (16). Stock cultures were maintained in 10-cm dishes (Falcon 3001) in Dulbecco's modified Eagle's medium (DME) supplemented with 10\% FCS (Gibco), glutamine $10 \mathrm{mM}$ (Gibco), penicillin $100 \mathrm{U} / \mathrm{ml}$, and streptomycin $100 \mu \mathrm{g} / \mathrm{ml}$ (Gibco). Media was changed every third day until growth was confluent (11 d), then the cells were removed by exposure to $0.1 \%$ trypsin, $0.03 \%$ EDTA (Gibco), and replated between cell densities of 10,000-12,000 cells $/ \mathrm{cm}^{2}$. To determine Sm-C/IGF-I binding to porcine aortic smooth muscle cells these cells were plated in 24-well 16-mm dishes (Falcon 3004) at a density of 6,000 cells $/ \mathrm{cm}^{2}$ in DME containing $10 \%$ FCS. After $6 \mathrm{~d}$ of incubation cells were washed extensively with PBS and then exposed to serum-free medium containing a $50 \%$ concentration of conditioned medium from either human fibroblast cultures or porcine aortic smooth muscle cells. After a 14-48-h incubation in DME containing the conditioned medium, the confluent monolayers were again washed extensively and ${ }^{125} \mathrm{I}-\mathrm{Sm}-\mathrm{C} / \mathrm{IGF}$ I $(80,000 \mathrm{cpm} /$ well $)$ was added to $0.25 \mathrm{ml}$ of DME supplemented with $20 \mathrm{mM}$ Hepes, $0.1 \%$ BSA, pH 7.4, and the incubation continued for 2 $\mathrm{h}$ at $8^{\circ} \mathrm{C}$. Specific binding of cell-associated ${ }^{125} \mathrm{I}-\mathrm{Sm}$-C/IGF-I was determined as described for the fibroblast cultures.

Affinity cross-linking studies. Affinity labeling was performed according to a modification of methods described by Adams et al. (17) and Wilkins and D'Ercole (18). Briefly, the conditioned media was incubated with ${ }^{125} \mathrm{I}-\mathrm{Sm}-\mathrm{C} / \mathrm{IGF}-\mathrm{I}$ at room temperature for $10 \mathrm{~min}$ in Hepes binding buffer with BSA $1 \%, \mathrm{pH} 7.4$, with or without varying concentrations of unlabeled Sm-C/IGF-I and insulin. The cross-linking agent, disuccinimidyl suberate (DSS; Pierce Chemical Co., Rockford, IL) was then added in a final concentration of $0.5 \mathrm{mM}$ and the samples incubated for 10 $\mathrm{min}$ at $22^{\circ} \mathrm{C}$. The reaction was stopped by the addition of $50 \mathrm{mM}$ Tris and the samples hydrolyzed by boiling for $5 \mathrm{~min}$. The proteins were then separated by $10 \%$ sodium dodecyl sulfate-polyacrylamide gel electrophoresis (SDS-PAGE).

For studies on the monolayer cultures the fibroblasts or smooth muscle cells were grown to confluency in 35-mm dishes (Falcon), washed three times with Hepes binding buffer containing BSA $1 \%, \mathrm{pH} 8.0$, and incubated with ${ }^{125} \mathrm{I}-\mathrm{Sm}-\mathrm{C} / \mathrm{IGF}-\mathrm{I}$ in the same buffer at $4^{\circ} \mathrm{C}$ for $2 \mathrm{~h}$ with or without varying concentrations of unlabeled Sm-C/IGF-I, insulin or the anti-type I-receptor monoclonal antibody. The hybridoma cell line producing the monoclonal antibody to the type I receptor, designated alpha-IR3, was a gift of Dr. Steven Jacobs (Burroughs Wellcome, Research Triangle Park, NC). This antibody, which is directed at the type I SmC/IGF-I receptor (19), was amplified in ascites fluid and purified by sequential precipitation in $18 \%$ and $15 \%$ sodium sulfate. In a preliminary study of the time of incubation (2-18 h), the longer incubations resulted in a slight increase in intensity of labeled bands seen on autoradiography, but in no differences in the protein species that bound to ${ }^{125} \mathrm{I}-\mathrm{Sm}-\mathrm{C} /$ IGF-I. The monolayers were then washed twice with cold Hepes buffer without BSA, $\mathrm{pH} 7.4$, and DSS was added in a final concentration of $0.1 \mathrm{mM}$ in $1.0 \mathrm{ml}$ of the same buffer. After a 10 -min incubation at room temperature, the reaction was quenched with 3 vol $10 \mathrm{mM}$ Tris, $\mathrm{pH} 7.0$, and $1 \mathrm{mM}$ EDTA. After $5 \mathrm{~min}$, the Tris-EDTA was aspirated and the cells were solubilized in $0.1 \mathrm{ml}$ of $50 \mathrm{mM}$ Tris, $2 \%$ SDS with or without $100 \mathrm{mM}$ dithiothreitol (DTT). The cell lysate was transferred to a 1.5$\mathrm{ml}$ microfuge tube and boiled for $5 \mathrm{~min}$, and the proteins were separated on $3-14 \%$ gradient SDS-PAGE (20). The gels were fixed with $10 \%$ acetic acid and $30 \%$ methanol, washed, dried, and then exposed to Kodak X-0 mat film (Eastman Kodak Co., Rochester, NY). The autoradiograms were then developed by standard techniques. The molecular weights of the standards used were: myosin 200,000; phosphorylase B 97,400, BSA 68,000 ; ovalbumin 43,000 ; alpha-chymotrypsinogen 25,700 ; beta-lactoglobulin 18,400; lysozyme 14,300 (Bethesda Research Laboratories, Gaithersburg, MD).

\section{Results}

Between $5 \%$ and $9 \%$ of the radiolabeled Sm-C/IGF-I bound to the fibroblast monolayers. When increasing concentrations of unlabeled Sm-C/IGF-I (1-20 ng/ml) were added, however, ${ }^{125} \mathrm{I}$ Sm-C/IGF-I binding increased $40-65 \%$ over basal and decreased only when concentrations were increased to between 25 and 300 
$\mathrm{ng} / \mathrm{ml}$ (Fig. 1). In contrast, when ${ }^{125} \mathrm{I}-\mathrm{Sm}-\mathrm{C} / \mathrm{IGF}-\mathrm{I}$ binding was determined using suspension cultures, low concentrations of SmC/IGF-I $(0.5-10 \mathrm{ng} / \mathrm{ml})$ displaced significant amounts of the labeled peptide (Fig. 1). To determine whether this phenomenon was limited to one fibroblast strain, monolayer cultures prepared from eight other fibroblast strains were analyzed for the capacity of Sm-C/IGF-I to displace labeled Sm-C/IGF-I. In all the cell lines tested, there was a significant increase in ${ }^{125} \mathrm{I}-\mathrm{Sm}-\mathrm{C} / \mathrm{IGF}-\mathrm{I}$ binding at low concentrations $(1-10 \mathrm{ng} / \mathrm{ml})$ and no lines showed $>29 \%$ displacement at the $50 \mathrm{ng} / \mathrm{ml}$ concentration (Table I).

Because high concentrations of unlabeled insulin have been shown to compete effectively for binding of ${ }^{125} \mathrm{I}-\mathrm{Sm}-\mathrm{C} / \mathrm{IGF}-\mathrm{I}$ to type I receptors, increasing concentrations of unlabeled insulin were incubated with ${ }^{125} \mathrm{I}-\mathrm{Sm}-\mathrm{C} / \mathrm{IGF}-\mathrm{I}$ to determine the capacity of this peptide to displace bound ${ }^{125} \mathrm{I}-\mathrm{Sm}-\mathrm{C} / \mathrm{IGF}-\mathrm{I}$ from the adherent monolayers and from cells in suspension. Unlabeled insulin displaced $60 \%$ of the labeled material from suspended cells (Fig. 2) but had no effect on binding of ${ }^{125} \mathrm{I}-\mathrm{Sm}$-C/IGF-I to the adherent monolayers. Again when eight other cell lines were tested unlabeled insulin was incapable of displacing ${ }^{125} \mathrm{I}-\mathrm{Sm}-\mathrm{C} /$ IGF-I from adherent cultures (Table I). It appears, therefore, that in monolayer culture most of the ${ }^{125} \mathrm{I}-\mathrm{Sm}-\mathrm{C} / \mathrm{IGF}-\mathrm{I}$ is binding to a site that does not bind insulin.

Alterations in the experimental conditions prior to performing the binding experiments on monolayers did not change the sensitivity of fibroblast ${ }^{125} \mathrm{I}-\mathrm{Sm}-\mathrm{C} / \mathrm{IGF}-\mathrm{I}$ binding to competition by unlabeled Sm-C/IGF-I. Specifically, when monolayer cultures were grown to densities between 20,000 and 150,000 cells $/ \mathrm{cm}^{2}$

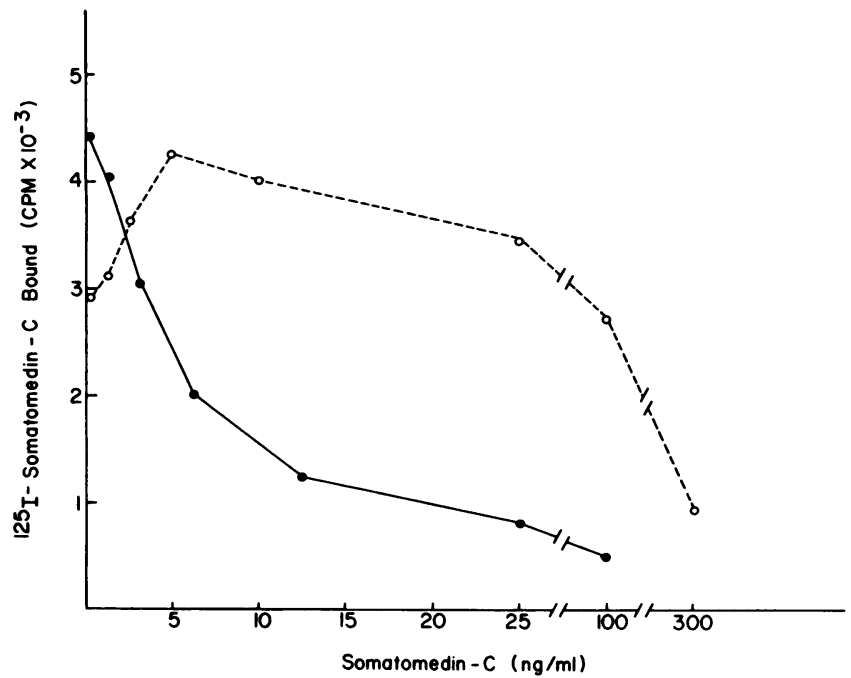

Figure 1. Binding of Sm-C/IGF-I to human fibroblast monolayers and cell suspensions. Human fibroblast monolayers $(0)$ were grown to confluency $(85,000$ cells/well) as described in methods. After extensive washing with PBS, $0.25 \mathrm{ml}$ of DME containing $25 \mathrm{mM}$ Hepes, $0.1 \%$ BSA, pH 7.4 was added. ${ }^{125} \mathrm{I}-\mathrm{Sm}-\mathrm{C} / \mathrm{IGF}-\mathrm{I}(80,000 \mathrm{cpm} /$ well $)$ was added and the incubation was continued for $2 \mathrm{~h}$ at $8^{\circ} \mathrm{C}$. The monolayers were then washed three times with PBS, solubilized in $0.3 \mathrm{~N}$ $\mathrm{NaOH}$, and the cell-associated radioactivity was determined. Cell suspensions $(\bullet)$ were prepared by exposing monolayer cultures to trypsin $0.1 \%$, EDTA $0.03 \%$ for $1 \mathrm{~min}$, and after transfer of $1.5 \times 10^{6}$ cells/ tube in $0.25 \mathrm{ml}$ of buffer, were incubated with $120,000 \mathrm{cpm}{ }^{125} \mathrm{I}-\mathrm{Sm}$ $\mathrm{C} / \mathrm{IGF}-\mathrm{I}$ for $2 \mathrm{~h}$ at $8^{\circ} \mathrm{C}$. After centrifugation, the cell associated ${ }^{125} \mathrm{I}$ $\mathrm{Sm}-\mathrm{C} / \mathrm{IGF}-\mathrm{I}$ was quantitated. Increasing concentrations of unlabeled $\mathrm{Sm}-\mathrm{C} / \mathrm{IGF}-\mathrm{I}(0-300 \mathrm{ng} / \mathrm{ml})$ were added simultaneously with ${ }^{125} \mathrm{I}-\mathrm{Sm}$ $\mathrm{C} / \mathrm{IGF}-\mathrm{I}$ to triplicate cultures and each point is the mean value.
Table I. Binding of Sm-C/IGF by Several Fibroblast Strains

\begin{tabular}{cllll}
\hline & & \multicolumn{2}{l}{$\%$ of control bound } \\
\cline { 3 - 4 } & & \multicolumn{2}{l}{ Sm-C/IGF added } & \\
\cline { 3 - 4 } Cell designation & Donor age & $3-6 \mathrm{ng} / \mathrm{ml}$ & $50 \mathrm{ng} / \mathrm{ml}$ & $\begin{array}{c}\text { Insulin added } \\
10 \mathrm{\mu g} / \mathrm{ml}\end{array}$ \\
\hline GM-10 & $12 \mathrm{wk}$ (fetal) & $133 \pm 7$ & $94 \pm 6$ & $91 \pm 9$ \\
4392 & $12 \mathrm{wk}$ (fetal) & $140 \pm 12$ & $104 \pm 5$ & $102 \pm 4$ \\
1523 & $3 \mathrm{~d}$ & $128 \pm 11$ & $87 \pm 9$ & $94 \pm 11$ \\
1437 & $3 \mathrm{~d}$ & $117 \pm 6$ & $91 \pm 11$ & $94 \pm 9$ \\
498 & $3 \mathrm{yr}$ & $112 \pm 11$ & $76 \pm 7$ & $95 \pm 2$ \\
1362 & $14 \mathrm{yr}$ & $130 \pm 2$ & $93 \pm 4$ & $98 \pm 6$ \\
6291 & $90 \mathrm{yr}$ & $114 \pm 10$ & $71 \pm 9$ & $99 \pm 13$ \\
731 & $96 \mathrm{yr}$ & $115 \pm 8$ & $82 \pm 10$ & $87 \pm 10$ \\
& & & & \\
\hline
\end{tabular}

* Control binding is defined as the amount of ${ }^{125} \mathrm{I}-\mathrm{Sm}-\mathrm{C} / \mathrm{IGF}-\mathrm{I}$ bound in the absence of any unlabeled SM-C/IGF-I.

or when the interval since the last media change prior to performing the binding experiment was varied from 1 to $5 \mathrm{~d}$, SmC/IGF-I binding was not altered. If the fibroblast monolayers were exposed to serum-free media for $48 \mathrm{~h}$ with two media changes prior to initiation of the experiment, however, the paradoxical increase in Sm-C/IGF-I binding was eliminated but the cultures were still relatively insensitive to competition by unlabeled Sm-C/IGF-I.

To investigate the possibility that in monolayer cultures SmC/IGF-I was binding to a site other than the type I receptor, a specific type I receptor monoclonal antibody (alpha-IR3) was added at increasing concentrations to both suspended and monolayer cultures and coincubated with ${ }^{125} \mathrm{I}-\mathrm{Sm}-\mathrm{C} / \mathrm{IGF}-\mathrm{I}$. This antibody caused no displacement of radiolabeled Sm-C/IGF-I from the monolayers cultures, even when concentrations as high as $10^{-7} \mathrm{M}$ were used, but competed effectively with ${ }^{125} \mathrm{I}-\mathrm{Sm}-\mathrm{C} /$

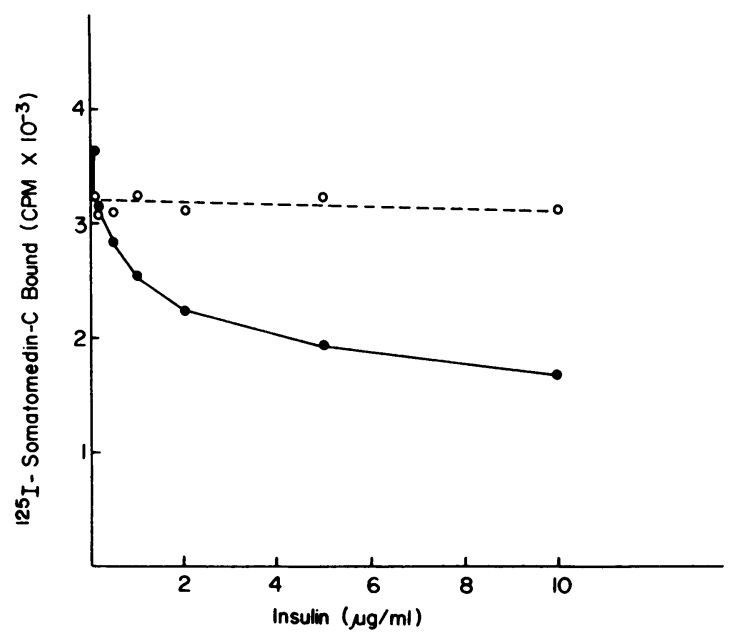

Figure 2. Competition between ${ }^{125} \mathrm{Sm}-\mathrm{C} / \mathrm{IGF}-\mathrm{I}$ and insulin for binding to fibroblast monolayers and suspension cultures. Both fibroblast monolayers ( $O$; density $=88,000$ cells/well) and suspension cultures (๑) were prepared as described in Fig. 1. After addition of increasing concentrations of insulin $(0-10 \mu \mathrm{g} / \mathrm{ml})$ the incubations were carried out and cell-associated ${ }^{125} \mathrm{I}-\mathrm{Sm}-\mathrm{C} / \mathrm{IGF}-\mathrm{I}$ was determined as described in Fig. 1. 


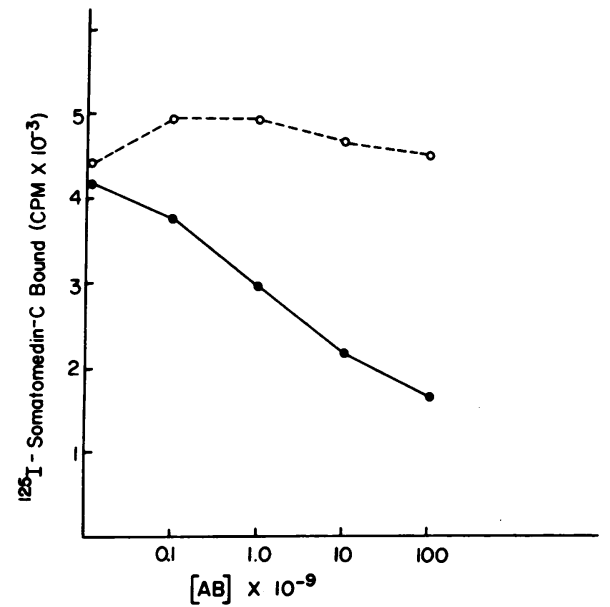

Figure 3. Competition between type I receptor antibody (alpha-IR3) and ${ }^{125} \mathrm{I}-\mathrm{Sm}$-C/IGF-I for binding to fibroblast monolayers $(77,000$ cells/well) and suspension cultures. Fibroblast monolayers ( 0 ) and suspension cultures $(\bullet)$ were prepared as described previously and were exposed to ${ }^{125} \mathrm{I}-\mathrm{Sm}-\mathrm{C} / \mathrm{IGF}-\mathrm{I}$ and increasing concentrations of antibody, $(0.1-100 \mathrm{nM})$ then incubated as in Fig. 1. Cell-associated radioactivity after the incubation was determined as in Fig. 1. Each point represents the mean of triplicate determinations.

IGF-I in suspension cultures (Fig. 3). This finding suggests that the ${ }^{125} \mathrm{I}-\mathrm{Sm}-\mathrm{C} / \mathrm{IGF}-\mathrm{I}$ is bound to a site other than type I receptor (i.e., a receptor that does not bind insulin such as the type II receptor), and that the type I receptor binding represents only a very low percentage of the total binding observed.

To determine the characteristics of the ${ }^{125} \mathrm{I}-\mathrm{Sm}-\mathrm{C} / \mathrm{IGF}-\mathrm{I}$ binding moiety, affinity cross-linking studies were performed. After cross-linking ${ }^{125} \mathrm{I}-\mathrm{Sm}-\mathrm{C} / \mathrm{IGF}-\mathrm{I}$-binding complexes from monolayer cultures were subjected to SDS-PAGE under reducing conditions and autoradiographed. Two major bands (Fig. 4) were observed: a 135,000-mol wt band, characteristic of the alphasubunit of the type I receptor, and a more intensely labeled band at 43,000 . A less intense band of $\sim 260,000 \mathrm{~mol}$ wt was also observed. The 260,000-, 135,000-, and 43,000-mol wt bands were either reduced in intensity or obliterated in the presence of $50 \mathrm{ng} / \mathrm{ml}$ unlabeled Sm-C/IGF-I. High concentrations of insulin $(20 \mu \mathrm{g} / \mathrm{ml})$ partially displaced labeled Sm-C/IGF-I from the 135,000-mol wt band and the 260,000-mol wt band, but not from the 43,000-mol wt band (Fig. 4). Similarly alpha-IR3 inhibited labeling of the 135,000 -mol wt subunit and the 260,000 mol wt band. In the presence of low concentrations of unlabeled Sm-C/IGF-I, however, the intensity of labeling of both the 135,000- and 43,000-mol wt bands was apparently increased (Fig. 5). To exclude the possibility that the binding protein in the 43,000-mol wt complex was associated with the culture dish or cellular matrix and not the cell surface, the matrix was extracted after cell removal with Triton $x-100$ and the counts per minute associated with the plastic surface also quantitated. Less than $8 \%$ of the total counts bound were detected in either the matrix or the dish.

To confirm that Sm-C/IGF-I binding to a protein in the 43,000-mol wt complex accounted for the lack of insulin displacement, quiescent fibroblast monolayers were suspended by trypsinization and incubated with ${ }^{125} \mathrm{I}-\mathrm{Sm}-\mathrm{C} / \mathrm{IGF}-\mathrm{I}$ for $4 \mathrm{~h}$ at $8^{\circ} \mathrm{C}$ in the presence and absence of unlabeled Sm-C/IGF-I or insulin and cross-linked and the proteins were separated by SDS-

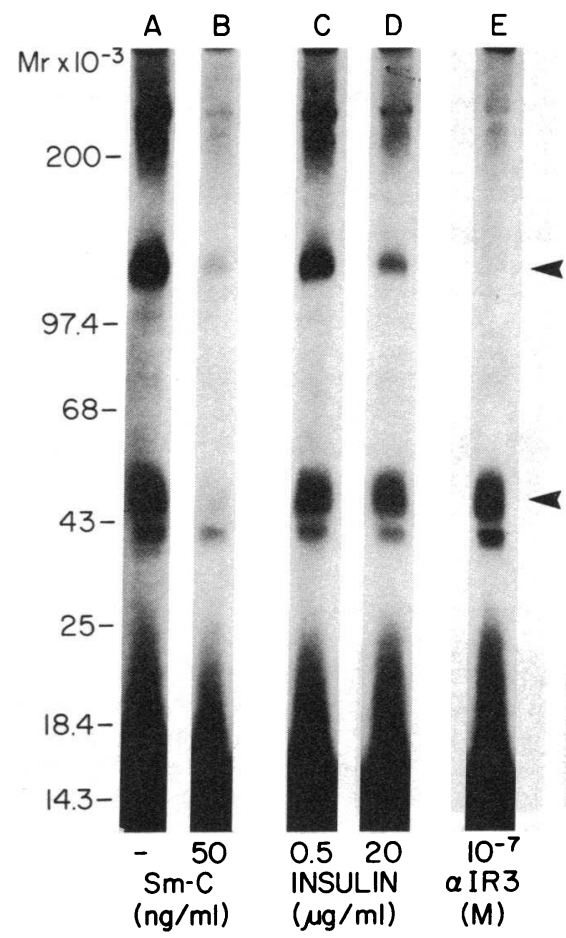

Figure 4. Autoradiogram of ${ }^{125}$ I-Sm-C/IGF-I cross-linked to fibroblast monolayers and separated on 3-14\% gradient SDS-PAGE after reduction with $100 \mathrm{mM}$ DTT. Lane $A$ : without competing unlabeled peptides, showing predominant binding of ${ }^{125} \mathrm{I}-\mathrm{Sm}$-C/IGF-I to the 135,000-mol wt alpha-subunit of type I Sm-C/IGF receptor and the 43,000-mol wt cell-associated, ${ }^{125} \mathrm{I}$-Sm-C/IGF-I binding protein complex. Lane $B$ : competition with unlabeled Sm-C/IGF-I $50 \mathrm{ng} / \mathrm{ml}$. Lanes $C$ and $D$ : competition with insulin, 0.5 and $20 \mu \mathrm{g} / \mathrm{ml}$, respectively, showing a significant reduction in ${ }^{125} \mathrm{I}-\mathrm{Sm}$-C/IGF-I binding to the 135,000 -mol wt alpha-subunit of type I receptor without reduction in binding in the 43,000-mol wt complex. Lane $E$ : competition with $10^{-7} \mathrm{M}$ alpha-IR3, showing selective competition of ${ }^{125} \mathrm{I}-\mathrm{Sm}-\mathrm{C} / \mathrm{IGF}-\mathrm{I}$ binding to the alpha-subunit of type I receptor and apparent increase in ${ }^{125} \mathrm{I}-\mathrm{Sm}-\mathrm{C} / \mathrm{IGF}-\mathrm{I}$ binding in the $43,000-\mathrm{mol}$ wt complex.

PAGE. In contrast to the monolayers no binding to the 43,000 mol wt protein was present and the ${ }^{125} \mathrm{I}-\mathrm{Sm}-\mathrm{C} / \mathrm{IGF}-\mathrm{I}$ was bound only to the 135,000-mol wt type I receptor (Fig. 6). The bound ${ }^{125} \mathrm{I}-\mathrm{Sm}-\mathrm{C} / \mathrm{IGF}-\mathrm{I}$ could be displaced with either unlabeled SmC/IGF-I, insulin, or alpha-IR3. Similar results were obtained if the cells were mechanically removed from the plate and not exposed to trypsin.

To determine whether this binding protein in the 43,000 mol wt complex could be secreted by the fibroblast monolayers into the culture medium, conditioned medium from the fibroblast monolayers was incubated with ${ }^{125} \mathrm{I}-\mathrm{Sm}-\mathrm{C} / \mathrm{IGF}-\mathrm{I}$ and reacted with DSS. After separation by PAGE, the ${ }^{125} \mathrm{I}-\mathrm{Sm}-\mathrm{C} / \mathrm{IGF}$ I was cross-linked to three fibroblast media proteins. The molecular weights of the complexes were $43,000,36,000$ and 25,000 (Fig. 7). The 43,000- and 36,000-mol wt bands were less intensely labeled after addition of unlabeled Sm-C/IGF-I and IGF-II, but not after addition of insulin. In contrast, when conditioned medium was collected for $72 \mathrm{~h}$ from suspension cultures and crosslinked to ${ }^{125} \mathrm{I} \mathrm{Sm}-\mathrm{C} / \mathrm{IGF}-\mathrm{I}$, no 43,000-mol wt binding moiety was detectable (data not shown).

To determine the functional significance of this 43,000-mol wt protein complex, conditioned medium from quiescent fibro- 


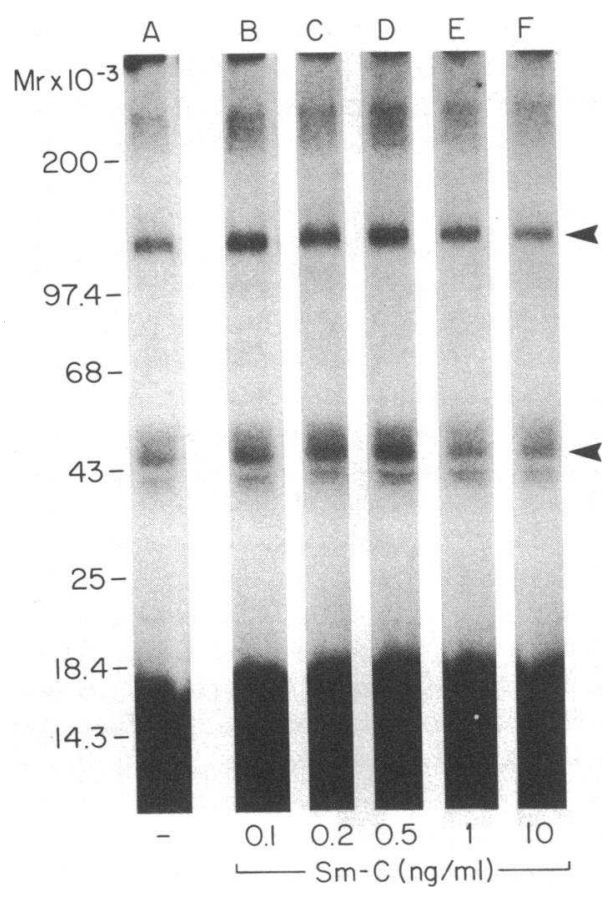

Figure 5. Autoradiogram of ${ }^{125} \mathrm{I}-\mathrm{Sm}$-C/IGF-I cross-linked to fibroblast monolayers and separated on 3-14\% gradient SDS-PAGE after reduction with $100 \mathrm{mM}$ DTT. Lane $A$ : without competing unlabeled peptides. Lanes $B-F$ : with increasing concentrations of unlabeled $\mathrm{Sm}-\mathrm{C} /$ IGF-I, from 0.1 to $10 \mathrm{ng} / \mathrm{ml}$, showing an increase in ${ }^{125} \mathrm{I}-\mathrm{Sm}-\mathrm{C} / \mathrm{IGF}-\mathrm{I}$ labeling of both 135,000 -mol wt alpha-subunit and the $43,000-\mathrm{mol}$ wt complex.

blast cultures obtained after $72 \mathrm{~h}$ of incubation was tested for its effects on the binding of ${ }^{125} \mathrm{I}-\mathrm{Sm}-\mathrm{C} / \mathrm{IGF}-\mathrm{I}$ to porcine aortic smooth muscle cells (a cell type that does not secrete a binding moiety capable of associating with the cell surface). We have shown that quiescent porcine aortic smooth muscle cell monolayers possess type I receptors and that the ${ }^{125} \mathrm{I}-\mathrm{Sm}-\mathrm{C} / \mathrm{IGF}-\mathrm{I}$ that binds to this receptor is displaceable by unlabeled Sm-C/IGF-I and insulin. After $24 \mathrm{~h}$ of exposure to either fibroblast or smooth muscle cell-conditioned medium, ${ }^{125} \mathrm{I}-\mathrm{Sm}$-C/IGF-I binding was determined. Control monolayers exposed to smooth muscle cellconditioned medium showed displacement of ${ }^{125} \mathrm{I}-\mathrm{Sm}-\mathrm{C} / \mathrm{IGF}-\mathrm{I}$ at low concentrations of unlabeled Sm-C/IGF-I $(1-5 \mathrm{ng} / \mathrm{ml})$, and concentrations of unlabeled insulin between 1 and $10 \mu \mathrm{g} /$ $\mathrm{ml}$ also caused significant displacement (Fig. 8). In contrast, cultures that were preincubated with fibroblast-conditioned medium showed a $60 \%$ increase in basal ${ }^{125} \mathrm{I}-\mathrm{Sm}-\mathrm{C} / \mathrm{IGF}-\mathrm{I}$ binding that further increased when increasing concentrations of unlabeled Sm-C/IGF-I were added. Addition of unlabeled Sm-C/ IGF-I in concentrations as high as $25 \mathrm{ng} / \mathrm{ml}$ were required to obtain any displacement, and insulin in concentrations as high as $1.0 \mathrm{mg} / \mathrm{ml}$ caused no displacement. To determine that this was not a property of one fibroblast line, conditioned media were obtained from eight different fibroblast strains and preincubated with smooth muscle cell monolayers. Media from all eight strains were shown to increase basal ${ }^{125} \mathrm{I}-\mathrm{Sm}-\mathrm{C} / \mathrm{IGF}-\mathrm{I}$ binding and to change the relative sensitivity to competition by unlabeled Sm-C/IGF-I (data not shown). Exposure of smooth muscle cell cultures to conditioned media obtained from fibroblast suspension cultures for $24 \mathrm{~h}$ did not result in changes in the binding of radiolabeled $\mathrm{Sm}-\mathrm{C}$. To determine whether a factor

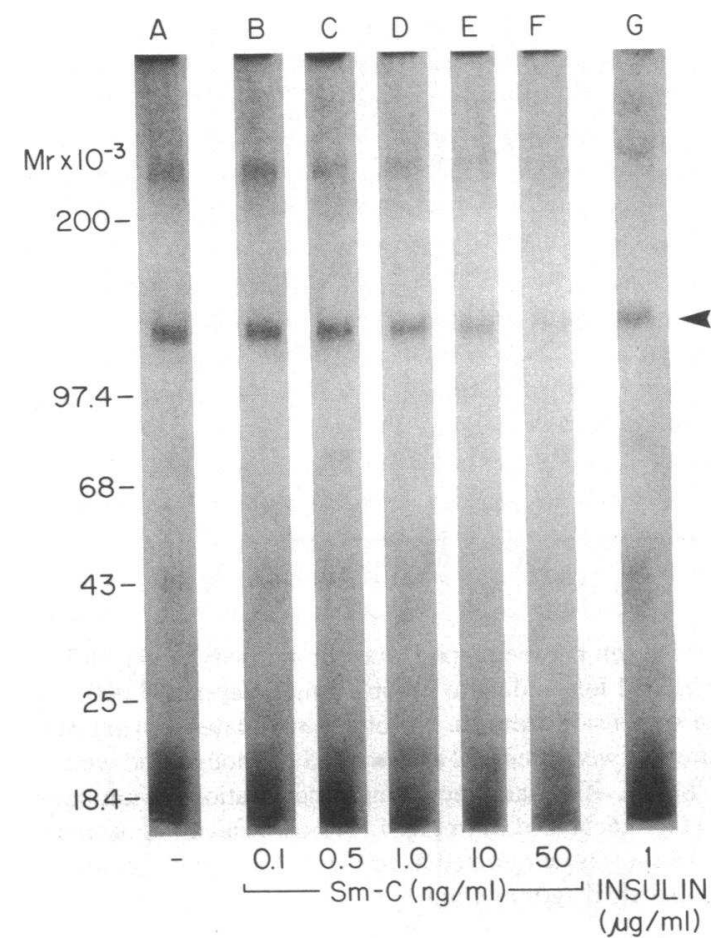

Figure 6. Autoradiogram of ${ }^{125} \mathrm{I}-\mathrm{Sm}-\mathrm{C} / \mathrm{IGF}-\mathrm{I}$ cross-linked to fibroblasts in suspension and separated on 3-14\% gradient SDS-PAGE after reduction with $100 \mathrm{mM}$ DTT. Lane $A$ : without competing unlabeled peptides, showing ${ }^{125} \mathrm{I}-\mathrm{Sm}-\mathrm{C} / \mathrm{IGF}-\mathrm{I}$ binding predominantly to $135,000-$ mol wt alpha-subunit of type I receptor, with little or no binding associated with the $43,000-\mathrm{mol}$ wt complex. Lanes $B-F$ : competition with increasing concentrations of unlabeled Sm-C/IGF-I. Lane $G$ : competition with insulin, $1 \mu \mathrm{g} / \mathrm{ml}$.

in fibroblast monolayer-conditioned media could alter Sm-C binding to suspended fibroblasts, 120,000 cells/tube were exposed to a $20 \%$ (vol/vol) concentration of fibroblast monolayer-conditioned medium (that had been concentrated fivefold) for 14 $h$ at $37^{\circ} \mathrm{C}$. After addition of increasing concentrations of unlabeled $\mathrm{Sm}-\mathrm{C}(1-10 \mathrm{ng} / \mathrm{ml}){ }^{125} \mathrm{I}-\mathrm{Sm}-\mathrm{C}$ binding increased $\sim 56 \%$ above basal at $4 \mathrm{ng} / \mathrm{ml}$ then decreased toward control levels.

To confirm that the effect of fibroblast-conditioned medium on ${ }^{125} \mathrm{I}-\mathrm{Sm}-\mathrm{C}$ binding to smooth muscle cells was associated with attachment of a protein represented in the 43,000-mol wt ${ }^{125} \mathrm{I}$ Sm-C/IGF-I-protein complex, cross-linking studies were performed using smooth muscle cells that had been exposed to fibroblast-conditioned medium. After exposure to this medium and cross-linking, ${ }^{125} \mathrm{I}-\mathrm{Sm}$-C/IGF-I was associated with three proteins in the smooth muscle cell monolayers (Fig. 9): a 135,000 -mol wt band that was lessened in intensity in the presence of insulin and obliterated by unlabeled Sm-C/IGF-I, a 43,000-mol wt band that could not be displaced with unlabeled insulin, and a 260,000-mol wt band. In contrast, control cultures that had been exposed to smooth muscle cell-conditioned media showed intense ${ }^{125} \mathrm{I}-\mathrm{Sm}$-C/IGF-I labeling in the 135,000 -mol wt band, as well as less intense labeling at 260,000 . Both bands were displaced with increasing unlabeled Sm-C/IGF-I or insulin. Of interest was the observation that cross-linking of radiolabeled Sm-C/IGF-I to smooth muscle cell-conditioned media showed that a 35,000-mol wt protein that bound radiolabeled $\mathrm{Sm}-\mathrm{C}$ was present. 


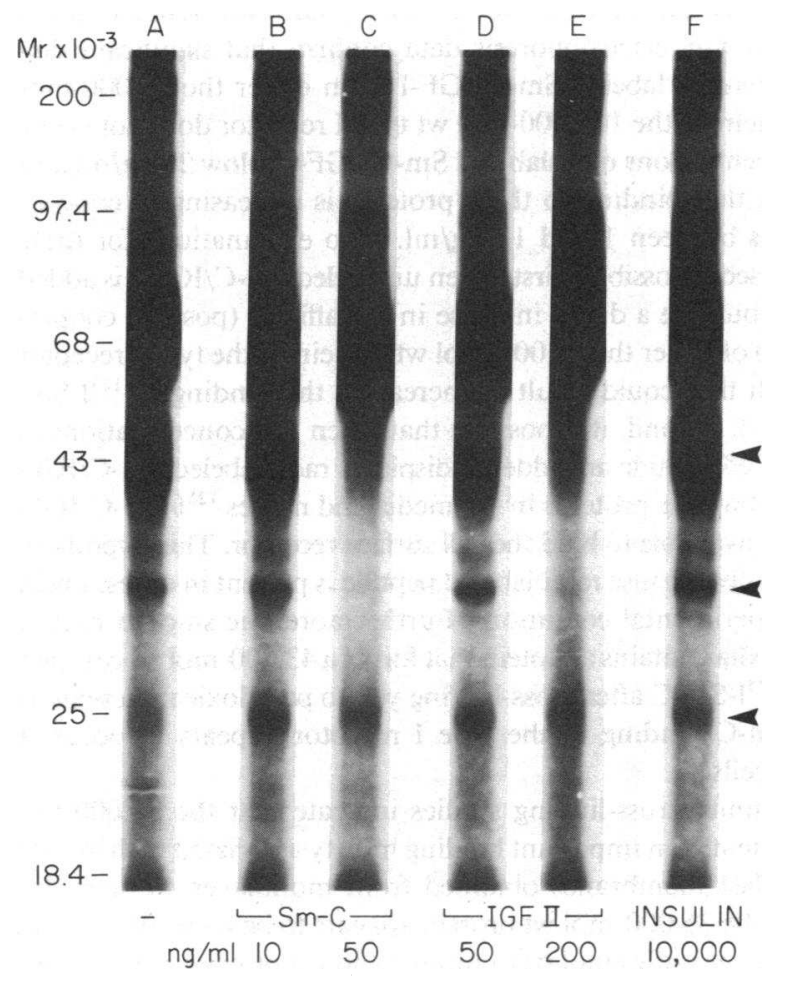

Figure 7. Autoradiogram of ${ }^{125} \mathrm{I}-\mathrm{Sm}-\mathrm{C} / \mathrm{IGF}-\mathrm{I}$ cross-linked to proteins in the conditioned medium from fibroblast monolayers (prepared as described in the text) and separated on 10\% SDS-PAGE after reduction with $10 \mathrm{mM}$ BME. Lane $A$ : without competing unlabeled peptides. Lanes $B$ and $C$ : competition with Sm-C/IGF-I, 20 and $50 \mathrm{ng} / \mathrm{ml}$, respectively, showing significant competition by $50 \mathrm{ng} / \mathrm{ml}$ of unlabeled peptide for ${ }^{125} \mathrm{I}-\mathrm{Sm}-\mathrm{C} / \mathrm{IGF}-\mathrm{I}$ binding associated with the 43,000 - and 36,000 -mol wt complexes and less significantly with the 25,000 -mol wt complex. Lanes $D$ and $E$ : competition with unlabeled IGF-II, 50 and $200 \mathrm{ng} / \mathrm{ml}$, which shows a competition by $200 \mathrm{ng} / \mathrm{ml}$ of this unlabeled peptide equivalent to unlabeled Sm-C/IGF-I, at $50 \mathrm{ng} / \mathrm{ml}$ (lane $C$ ). Lane $F$ : competition with unlabeled insulin, $10 \mu \mathrm{g} / \mathrm{ml}$, showing no competition to ${ }^{125} \mathrm{I}-\mathrm{Sm}-\mathrm{C} / \mathrm{IGF}-\mathrm{I}$ binding associated with the 43,000-, $36,000-$, and $25,000-\mathrm{mol}$ wt complexes.

Preliminary physicochemical properties of the factor in the 43,000-mol wt ${ }^{125} \mathrm{I}-\mathrm{Sm}-\mathrm{C} / \mathrm{IGF}-\mathrm{I}$ protein complex are: $(a)$ it is retained by dialysis using 3,500 -mol wt exclusion membrane, destroyed by proteases, $(b)$ it is heat stable at $56^{\circ} \mathrm{C}$ for $2 \mathrm{~h}$ but partially inactivated by heating to $80^{\circ} \mathrm{C}$ for $1 \mathrm{~h}$, and $(c)$ it is stable at pH 2.5 and 10.6 (Table II).

\section{Discussion}

These findings demonstrate that cultured human fibroblast monolayers secrete a $35,000-\mathrm{mol} \mathrm{wt}$ protein $(43,000$ minus 7,600 , the molecular weight of $\left.{ }^{125} \mathrm{I}-\mathrm{Sm}-\mathrm{C} / \mathrm{IGF}-\mathrm{I}\right)$ into culture medium. This protein is capable of binding Sm-C/IGF-I and alters Sm-C/IGF-I binding to fibroblast monolayers. Furthermore, our affinity-labeling and competition studies suggest that it is the major binding species detectable after cross-linking to confluent monolayers. The protein has the characteristics of a Sm-C/IGF-I-binding protein because it is secreted by cultured cells into the media, binds Sm-C/IGF-I avidly, and does not bind insulin. The property that appears to distinguish it from other Sm-C/IGF-I-binding proteins secreted by fibroblasts is that
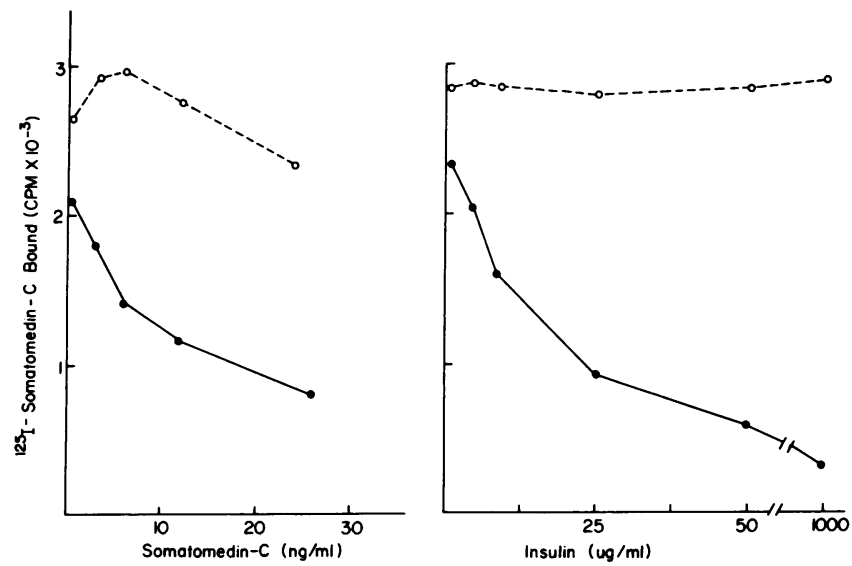

Figure 8. Binding of ${ }^{125} \mathrm{I}-\mathrm{Sm}-\mathrm{C} / \mathrm{IGF}-\mathrm{I}$ to smooth muscle cell monolayers after exposure to fibroblast conditioned medium. Smooth muscle cell monolayers $(92,000$ cells/well) were exposed to fibroblast $(0)$ or smooth muscle cell (๑)-conditioned medium for $24 \mathrm{~h}$ at $37^{\circ} \mathrm{C}$. After incubation the cultures were washed extensively, and ${ }^{125} \mathrm{I}-\mathrm{Sm}-\mathrm{C} / \mathrm{IGF}-\mathrm{I}$ $(80,000 \mathrm{cpm} /$ well $)$ was added. Increasing concentrations of unlabeled Sm-C/IGF-I (left) and insulin (right) were added to triplicate cultures. Cell-associated radioactivity was determined as in Fig. 1.

it appears to associate with cellular membranes of both fibroblasts and smooth muscle cells. The latter characteristic is not common to all fibroblast-secreted Sm-C/IGF-I-binding proteins, because we found no evidence of an association of the fibroblast media 36,000- and 25,000-mol wt ${ }^{125} \mathrm{I}-\mathrm{Sm}-\mathrm{C} / \mathrm{IGF}-\mathrm{I}-$ binding protein complexes with either fibroblast or smooth muscle cell lysates. It is possible that these binding proteins are not unique species
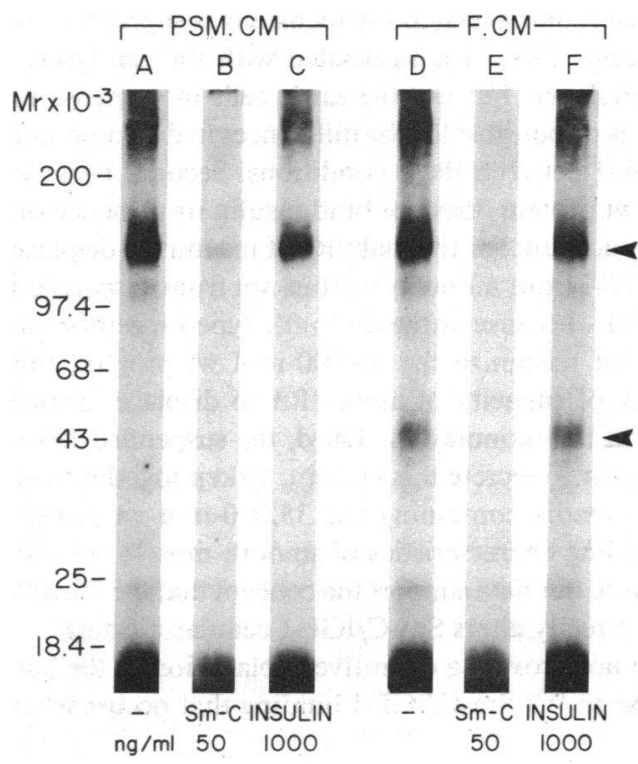

Figure 9. Autoradiogram of ${ }^{125} \mathrm{I}-\mathrm{Sm}-\mathrm{C} / \mathrm{IGF}-\mathrm{I}$ cross-linked to porcine smooth muscle cell monolayers and separated on 3-14\% gradient SDS-PAGE after reduction with $100 \mathrm{mM}$ DTT. Lanes $A-C$ : incubation was performed in conditioned medium from pig smooth muscle cells. Lanes $D-F$ : incubation was performed in conditioned medium from fibroblasts. Lanes $A$ and $D$ : without competing unlabeled peptides. Lanes $B$ and $E$ : competition with $50 \mathrm{ng} / \mathrm{ml} \mathrm{Sm-C/IGF-I.} \mathrm{Lanes}$ $C$ and $F$ : competition with unlabeled insulin, $1 \mu \mathrm{g} / \mathrm{ml}$. 
Table II. Effect of Heat, pH, and Proteolysis on the Activity of Fibroblast-conditioned Media

\begin{tabular}{ll}
\hline Condition & ${ }^{125}$ I-Sm-C/IGF-I binding \\
\hline & $\%$ of control \\
No treatment & 205 \\
pH 2.5 & 191 \\
pH 10.6 & 213 \\
$56^{\circ} \mathrm{C} 2 \mathrm{~h}$ & 183 \\
$80^{\circ} \mathrm{C} 1 \mathrm{~h}$ & 99 \\
$-20^{\circ} \mathrm{C} 1$ wk & 186 \\
$-70^{\circ} \mathrm{C} 1$ wk & 177 \\
Protease treatment 2 h $37^{\circ} \mathrm{C}$ & 94
\end{tabular}

Conditioned media was collected from fibroblast monolayers after a 72-h incubation. It was concentrated 33-fold by lyophilization then exposed to the perturbation listed. Acidification and base exposure were conducted for $30 \mathrm{~min}$ at room temperature. The protease preparation was a mixture of proteolytic enzymes obtained from Streptomyces griseus linked to agarose purchased from Sigma Chemical Co. It was used at a final concentration of $0.04 \mathrm{U} / \mathrm{ml}$.

but represent proteolytic cleavage products of the binding moiety in the $43,000-\mathrm{mol}$ wt complex that have retained the capacity to bind Sm-C/IGF-I but not to the cell surface. Whether or not this is the case the binding protein in the 43,000-mol wt moiety appears to be unique because it can associate with the cell surface. Furthermore, after exposure to this protein competition of unlabeled Sm-C/IGF-I or insulin for ${ }^{125} \mathrm{I}-\mathrm{Sm}-\mathrm{C} / \mathrm{IGF}-\mathrm{I}$ binding to smooth muscle cells is greatly altered, suggesting that the 35,000 mol wt protein may directly alter binding to the type I receptor.

The conclusion that the $35,000-\mathrm{mol}$ wt protein accounts for the differences observed in radiolabeled Sm-C/IGF-I binding between fibroblast monolayers and suspensions is supported by several observations. First, it is associated with the cell lysates of fibroblast monolayers but not the same cells in suspension, suggesting that it is responsible for the differences in displacement of ${ }^{125} \mathrm{I}-\mathrm{Sm}-\mathrm{C} / \mathrm{IGF}-\mathrm{I}$ between these conditions. Second, because the 35,000-mol wt protein does not bind insulin its presence on monolayers may account for the inability of insulin ${ }^{2}$ to displace labeled Sm-C/IGF-I from monolayers (but not from suspension cultures). Similarly, because antibody to the type I receptor (alpha-IR3) does not recognize the $35,000-\mathrm{mol}$ wt protein, this explains the lack of capacity of alpha-IR3 to displace labeled Sm-C/IGF-I from the monolayers. Third, the suspended fibroblasts do not appear to secrete this protein. Taken together with our finding that media containing the 35,000 -mol wt protein can alter the binding characteristics of smooth muscle cultures in a similar fashion, our data support the concept that the 35,000mol wt protein directly alters Sm-C/IGF-I cellular binding.

Our data do not provide a definitive explanation of the paradoxical increase in ${ }^{125} \mathrm{I}-\mathrm{Sm}-\mathrm{C} / \mathrm{IGF}-\mathrm{I}$ binding that occurs when

2. It is also possible that some ${ }^{125} \mathrm{I}-\mathrm{IGF}-\mathrm{I} / \mathrm{Sm}-\mathrm{C}$ is bound to type II receptors and, therefore, cannot be displaced with insulin. A 260,000-mol wt band was detected after cross-linking but insulin and alpha-IR 3 could compete with ${ }^{125} \mathrm{I}-\mathrm{IGF}-\mathrm{I} / \mathrm{Sm}-\mathrm{C}$ for binding to this protein, suggesting that it is a dimer of the alpha-subunit of the type I receptor and not the type II receptor. Nevertheless, it is possible that the type II receptor was not efficiently extracted with SDS and is present in greater concentration than our extraction method would indicate. low concentrations of unlabeled Sm-C/IGF-I are added to these cultures. Gel electrophoresis data confirm that significant displacement of labeled Sm-C/IGF-I from either the 35,000-mol wt protein or the $135,000-\mathrm{mol}$ wt type I receptor does not occur at concentrations of unlabeled Sm-C/IGF-I below $20 \mathrm{ng} / \mathrm{ml}$ and suggest that binding to these proteins is increasing at concentrations between 1 and $10 \mathrm{ng} / \mathrm{ml}$. Two explanations for these results seem possible. First, when unlabeled Sm-C/IGF-I is added there could be a direct increase in the affinity (positive cooperativity) of either the $35,000-\mathrm{mol} w t$ protein or the type I receptor or both that could result in increasing the binding of ${ }^{125} \mathrm{I}-\mathrm{Sm}$ $\mathrm{C} / \mathrm{IGF}-\mathrm{I}$. Second, it is possible that when low concentrations of unlabeled peptide are added it displaces radiolabeled Sm-C/IGFI from binding proteins in the media and makes ${ }^{125} \mathrm{I}-\mathrm{Sm}-\mathrm{C} / \mathrm{IGF}-$ I more available to bind the cell surface receptor. This hypothesis is unlikely because radiolabeled peptide is present in excess under the experimental conditions. Furthermore, the smooth muscle cell media contains a protein that forms a 43,000-mol wt complex with ${ }^{125} \mathrm{I}-\mathrm{Sm}-\mathrm{C}$ after cross-linking yet no paradoxical increase in ${ }^{125} \mathrm{I}-\mathrm{Sm}-\mathrm{C}$ binding to the type $\mathrm{I}$ receptor appears to occur in these cells.

Affinity cross-linking studies indicate that the $35,000-\mathrm{mol}$ wt protein is an important binding moiety associated with human fibroblast membranes obtained from monolayer cultures. Because the $35,000-\mathrm{mol}$ wt protein appears to be a specific binding component of monolayer cultures and is not present in suspension cultures, it is possible that this protein is associated with the basement membrane of the monolayers. However, direct binding studies to basement membranes after cell removal showed very low levels of binding and after cross-linking to this material no 43,000-mol wt complex was detected. Furthermore, the 43,000-mol wt complex can be detected on the suspended cell surfaces if these cells are exposed to concentrated monolayerconditioned media prior to the addition of cross-linking reagents. These data support the conclusion that the 43,000-mol wt complex is cell surface-associated.

The presence of this protein adds a third complex variable to understanding the binding of Sm-C/IGF-I to this cell type. Knauer and Cunningham (21) have reported that human fibroblasts secrete a protein that binds covalently to epidermal growth factor (EGF) binding protein (termed a protease nexin) and functions to enhance EGF binding to cultured fibroblast monolayers. Although the 35,000-mol wt protein reported here does not bind Sm-C/IGF-I covalently, it may function in a similar manner. This or a very similar protein may have previously been observed during preparation of membrane fractions from tissues. Grizzard et al. (22) noted a 45,000-mol wt ${ }^{125} \mathrm{I}-\mathrm{Sm}-\mathrm{C} /$ IGF-I-binding protein complex in preparations of placental membrane preparations from preterm placentas. Likewise, Armstrong et al. (23) used placental membranes and noted a band between 40,000 and 45,000 that cross-linked with labeled basic somatomedin. Although in the former study amniotic fluid was thought to be the source of the protein, it is notable that it was not completely removed by washing. Because fibroblasts are present in these tissues it is possible that these authors were cross-linking to a protein related to the one described herein. Finally, multiple studies report somatomedin-binding proteins of similar size in amniotic fluid, serum, and culture media (11, 18, 23).

Other investigators have prepared human fibroblast membranes from suspension cultures for cross-linking studies and have not reported this protein (7). Because they detached the 
cells from the monolayer it is possible that the 35,000 protein was removed, or alternately, as shown by Grizzard et al. (22), it might not have been detected because $5 \%$ polyacrylamide gels were used. Our data support the hypothesis that removal of the cells from the plate results in a lower cellular affinity for the 35,000-mol wt protein because exposure of suspended cells to concentrated conditioned media prior to binding studies results in reinstitution of the paradoxical increase in ${ }^{125} \mathrm{I}-\mathrm{Sm}-\mathrm{C} / \mathrm{IGF}-\mathrm{I}$ binding. Inasmuch as the suspended cells do not secrete the 35,000-mol wt binding protein its continued synthesis and secretion during the binding experiment may be required for it to be detected. In contrast, when affinity cross-linking studies have been performed by other investigators directly on fibroblast monolayers not only is the type I receptor present but a lower molecular weight IGF-I complex $(43,000)$ is also present $(5)$. Taken together, these findings suggest that this binding moiety may be important in modifying the binding, and possibly the biologic action of Sm-C/IGF-I in many types of proliferating cells.

These findings are difficult to reconcile with published reports of Rosenfeld and Dollar (9). They have reported that unlabeled Sm-C/IGF-I displaces significant quantities of labeled peptide from newborn foreskin fibroblast monolayers when added in concentrations of $1-10 \mathrm{ng} / \mathrm{ml}$. In their hands addition of insulin at $8.0 \mu \mathrm{g} / \mathrm{ml}$ results in a $60 \%$ displacement of bound ${ }^{125} \mathrm{I}-\mathrm{Sm}-\mathrm{C} /$ IGF-I from monolayer cultures, and their results are consistent with the existence of only one class of receptors. Differences between our studies and theirs cannot be attributable to tissue source, donor age, feeding schedule, or preincubation periods, as each were similar or identical. Because these authors did not detail the plating densities utilized nor the purity of the peptides employed, it remains possible that those differences account for the discrepancies noted for Sm-C/IGF-I displacement. The discrepancies in the findings of insulin displacement remain unresolved.

These findings indicate that fibroblasts secrete a protein that functions not only to alter Sm-C/IGF-I binding to human fibroblast receptors but also has the potential for altering cellular response to this peptide. Our laboratory has previously described the secretion of a somatomedinlike factor by fibroblasts that augments the cellular response to exogenously added Sm-C/IGFI (24). Therefore, it is possible that the $35,000-\mathrm{mol}$ wt protein represents a closely related factor. Fibroblast DNA synthesis can be stimulated by very low concentrations of Sm-C/IGF-I (e.g., $1-10 \mathrm{ng} / \mathrm{ml}$ ). This finding indicates that the 35,000-mol wt protein may not be blocking the response to Sm-C/IGF-I in that the relatively high concentrations required for competition in these studies (e.g., $25-300 \mathrm{ng} / \mathrm{ml}$ ) are not required for replication: It is possible that this factor actually enhances the cellular responsiveness to exogenously added Sm-C/IGF-I. Secretion of this factor could represent an important signal molecule in cellcell interaction between fibroblasts or between fibroblasts and smooth muscle cells. In this regard there is evidence that after injury to vessel walls fibroblasts may suppress smooth muscle cell division and proliferate in areas where smooth muscle cells previously have dominated (25). Further studies will be required to analyze the effect of this peptide on smooth muscle cell division.

\section{Acknowledgments}

The authors gratefully acknowledge the help of Dr. Marjorie Svoboda who purified the Sm-C/IGF-I and IGF-II used in these studies. We are grateful for secretarial assistance of Ms. Geri Cox who prepared the manuscript.

This work was supported by grants AM-1022, HL-26306, HD-08299, AG-02331, and RR-00046 from the National Institutes of Health. Victor Han is a recipient of a fellowship from the Canadian Medical Research Council. A Joseph D'Ercole is the recipient of a Research Cancer Development Award from National Institute of Child Health and Human Development (HD-00435). Judson J. Van Wyk is a recipient of a Career Research Award K06 AM14115 and a Research Training Grant AM 07129 from the National Institute of Arthritis, Metabolic and Digestive Diseases, and Kidney.

\section{References}

1. Rechler, M. M., J. M. Podoskalny, I. D. Goldfine, and C. A. Wells. 1974. DNA synthesis in human fibroblasts is stimulated by insulin and by non-suppressible insulin-like activity (NSILA-S). J. Clin. Endocrinol. Metab. 39:512-521.

2. Conover, C. A., L. A. Dollar, R. L. Hintz, and R. G. Rosenfeld. 1983. Insulin-like growth factor I/somatomedin-C (IGF-I/Sm-C) and glucocorticoids synergistically regulate mitosis in competent fibroblasts. J. Cell. Physiol. 116:191-197.

3. Van Obberghen-Schilling, E. E., M. M. Rechler, J. A. Romanus, A. B. Knight, S. P. Nissley, and R. E. Humble. 1981. Receptors for insulinlike growth factor $I$ are defective in fibroblasts cultured from a patient with leprechanism. J. Clin. Invest. 68:1356-1365.

4. D'Ercole, A. J., L. E. Underwood, J. Groelke, and A. J. D. Plet. 1979. Leprechanism: studies of the relationship among hyperinsulinism insulin resistance and growth retardation. J. Clin. Endocrinol. Metab. 48:495-502.

5. Rechler, M. M. 1982. Leprechaunism and related syndromes with primary insulin resistance: heterogeneity of molecular defects. In Membranes and Genetic Disease. J. R. Sheppard, V. E. Anderson, and J. W. Eaton, editors. Alan R. Liss, Inc., New York. 245-281.

6. Kasuga, M., E. E. Van Obberghen-Schilling, S. P. Nissley, and M. M. Rechler. 1981. Demonstration of two subtypes of insulin like growth factor receptors by affinity crosslinking. J. Biol. Chem. 256:53055308.

7. Massague, J., and M. P. Czech. 1982. The subunit structures of two distinct receptors for insulinlike growth factors I and II and their relationship to the insulin receptor. J. Biol. Chem. 257:5038-5045.

8. Baldwin, D., M. Prince, D. T. Sai, C. Johnson, A. H. Rubenstein, and J. M. Olefsky. 1981. Insulin binding internalization and insulin receptor regulation in cultured human fibroblasts. Am. J. Physiol. 241: E251-258. i

9. Rosenfeld, R. G., and L. A. Dollar. 1982. Characterization of the somatomedin-C insulin like growth factor (Sm-C/IGF-I) receptor on cultured human fibroblast monolayers: regulation of receptor concentrations by Sm-C/IGF-I and insulin. J. Clin. Endocrinol. Metab. 55:434440.

10. Rosenfeld, R. G., L. A. Dollar, and C. A. Conover. 1984. Density associated loss of functional receptors for somatomedin-C/insulin like growth factor I (Sm-C/IGF-I) on cultured human fibroblast monolayers. J. Cell. Physiol. 121:419-424.

11. Rechler, M. M., and S. P. Nissley. 1985. The nature and regulation of the receptors for insulin like growth factors. Annu. Rev. Physiol. 47: $427-445$.

12. Clemmons, D. R., and D. S. Shaw. 1983. Variables controlling somatomedin production by cultured human fibroblasts. J. Cell. Physiol. 115:137-143.

13. Svoboda, M. E., and J. J. Van Wyk. 1985. Purification of somatomedin-C/insulin-like growth factor I. Methods Enzymol. 109:798816.

14. D'Ercole, A. J., L. E. Underwood, J. J. Van Wyk, C. J. Decedue, and D. B. Foushee. 1976. Specificity, topography, and ontogeny of the somatomedin-C receptor in mammalian tissues. In Proceedings of the Third International Symposium on Growth Hormone and Related Peptides. Excepta Medica, Amsterdam. 190-201.

15. Van Wyk, J. J., D. C. Graves, S. J. Casella, and S. Jacobs. 1985. 
Evidence from monoclonal antibody studies that insulin stimulates DNA synthesis through the type I somatomedin receptor. J. Clin. Endocrinol. Metab. 61:639-643.

16. Ross, R. R. 197.1. The smooth muscle cell II: growth of smooth muscle in culture and formation of elastic fibers. J. Cell Biol. 50:172186.

17. Adams, S. O., S. P. Nissley, M. Kasuga, T. P. Foley, and M. M. Rechler. 1983. Receptors for insulin like growth factors and growth effects of multiplication stimulating activity (rat insulinlike growth factor II) in rat embryo fibroblasts. Endocrinology. 112:971-978.

18. Wilkins, J. R., and A. J, D'Ercole. 1985. Affinity labelled plasma somatomedin-C/insulinlike growth factor I. Binding Proteins: evidence of growth hormone dependence and subunit structures. J. Clin. Invest. 75:1350-1358.

19. Kull, F. C., Jr., S. Jacobs, Y. U. Sue, M. E. Svoboda, J. J. Van Wyk, and P. Cuatracasas. 1983. Monoclonal antibodies to receptors for insulin and somatomedin-C. J. Biol. Chem. 258:6561-6566.

20. Chernausek, S. D., S. Jacobs, and J. J. Van Wyk. 1981. Structural similarities between human receptors for somatomedin- $\mathrm{C}$ and insulin: analysis by affinity labelling. Biochemistry. 20:7345-7350.

21. Knauer, D., and D. D. Cunningham. 1982. Epidermal growth factor carrier protein binds to cells via a complex with released carrier protein nexin. Proc. Natl. Acad. Sci. USA. 79:2310-2314.

22. Grizzard, J. D., A. J. D'Ercole, J. R. Williams, B. M. MoatesStaats, and R. W. Williams. 1984. Affinity labelled somatomedin-C receptors and binding proteins from the human fetus. J. Clin. Endocrinol. Metab. 58:535-542.

23. Armstrong, G. D., M. D. Hollenberg, B. Bhaumick, and R. M. Bala. 1982. Comparative studies of human placental insulin and basic somatomedin receptor. J. Cell. Biochem. 20:283-288.

24. Clemmons, D. R., L. E. Underwood, and J. J. Van Wyk. 1981. Hormonal control of somatomedin production by human fibroblasts. $J$. Clin. Invest. 67:10-17.

25. Armstrong, M. L., D. D. Heistead, M. L. Morus, D. J. Piegors, and F. M. Abboud. 1983. Hemodynamic sequalae of regression of experimental atherosclerosis. J. Clin. Invest. 71:104-113. 